\begin{tabular}{c|c|c}
\hline JURNAL PENELITIAN FARMASI HERBAL & VOL. 1 NO. 2 & $\begin{array}{c}\text { EDITION: NOVEMBER 2018 - } \\
\text { APRIL 2019 }\end{array}$ \\
\cline { 1 - 2 } & http://ejournal.delihusada.ac.id/index.php/JPFH & \\
\cline { 2 - 3 } RECEIVED: 17 FEBRUARI 2019 & ACCEPTED: 25 APRIL 2019 \\
\hline
\end{tabular}

\title{
ANTIBAKTERI SENYAWA FENOLIK DARI DAUN SAPUTANGAN (Maniltoa Grandiflora (A. Gray) Scheff)
}

\author{
Jhon Patar Sinurat, Saadah Siregar \\ Institut Kesehatan Medistra Lubuk Pakam, Jl. Sudirman No. 38, Lubuk Pakam \\ E-Mail : jhonpatar12@gmail.Com
}

\begin{abstract}
The Phytochemical screening test to identify secondary metabolites of Saputangan leaves extract (Maniltoa grandiflora (A.Gray) Scheff) showed positive results on phenolic and terpenoid compounds. The reagent used for phenolic screening was 5\% FeCl 3 and reagent for screening terpenoid was $1 \% \mathrm{CeSO}_{4}$ in $10 \% \mathrm{H}_{2} \mathrm{SO}_{4}$. Antibacterial test was carried out by agar diffusion method on extracts of DMSO Saputangan leaves. Phenolic compound obtained from extract of Saputangan leaves were 36.96 gram where the result was obtained after maceration, partitioning and evaporation processes. Antibacterial of phenolic compound was observed based on inhibitory zone diameters of phenolic compounds formed using paper discs with a diameter of $6 \mathrm{~mm}$. The diameters of the inhibition zone against Escherichia coli bacteria are 8.1; 8.5 and $9.7 \mathrm{~mm}$ larger than the diameter of the inhibition zone in Staphylococcus aureus bacteria at 7.3; 7.8 and $8.5 \mathrm{~mm}$. Then it can be stated that DMSO extracts of phenolic compound with concentrations $(0.25 ; 0.50$ and $1.00 \mathrm{mg} / \mathrm{ml})$ have antibacterial strength at the medium level where the average inhibition zone of $S$. aureus bacteria is $7.87 \mathrm{~mm}$ and the average inhibition zone in E. coli bacteria is $8.76 \mathrm{~mm}$.
\end{abstract}

\section{Keywords: Screening, Phenolic Compound, Antibacterial.}

\section{PENDAHULUAN}

Tumbuhan merupakan salah satu sumber yang penting dalam menghasilkan obatobatan karena tumbuhan mengandung senyawa bioaktif (Mahidol et al., 2002). Berbagai senyawa bioaktif yang dimiliki oleh tumbuhan-tumbuhan telah banyak diidentifikasi, diisolasi dan diekstraksi sehingga senyawa yang bersifat bioaktif dapat dimanfaatkan sebagai antibakteri, antifungi, antivirus dan antiparasit dan lainnya (Keller dan Nugraha, 2011).

Tumbuhan Saputangan (Maniltoa grandiflora(A.Gray) Scheff) merupakan salah satu jenis tumbuhan yang termasuk dalam genus Maniltoa dan famili Fabaceae. Tumbuhan saputangan biasa dijadikan sebagai tanaman hias yang dapat mengurangi polusi dengan menyerap polutan seperti karbon monoksida (Hidayati et al., 2013).
Famili Fabaceae (Polong-polongan) sebagian besar berkhasiat sebagai tumbuhan obatobatan. Bagian yang dimanfaatkan sebagai obat antara lain daun, bunga, kulit akar, dan kulit batang. Jenis fabaceae mengandung berbagai zat metabolit yang memiliki khasiat sebagai obat demam, batuk, TBC, obat cacing, obat sakit perut, obat kulit, pegalpegal, dan salep mata. (Solikin, 2009).

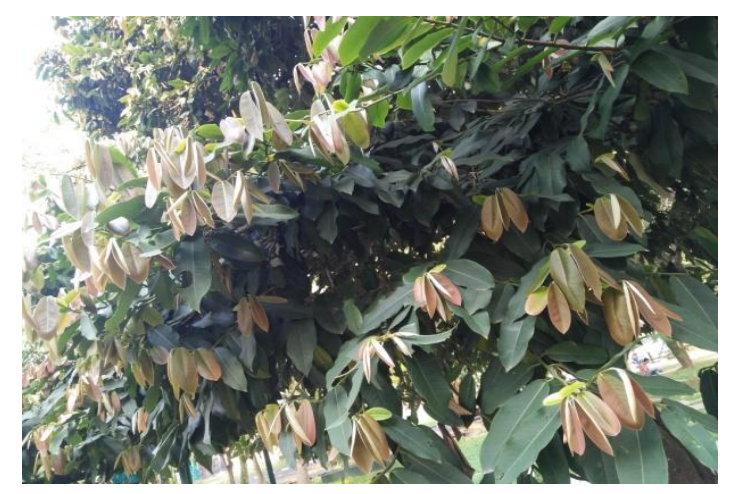

Gambar 1 Daun Tumbuhan Saputangan 


\begin{tabular}{c|c|c}
\hline JURNAL PENELITIAN FARMASI HERBAL & VOL. 1 NO. 2 & $\begin{array}{c}\text { EDITION: NOVEMBER 2018 } \\
\text { APRIL 2019 }\end{array}$ \\
\hline & http://ejournal.delihusada.ac.id/index.php/JPFH & \\
\cline { 2 - 2 } RECEIVED: 17 FEBRUARI 2019 & ACCEPTED: 25 APRIL 2019 \\
\hline
\end{tabular}

Senyawa fenolik merupakan senyawa yang memiliki satu atau lebih gugus hidroksil yang menempel pada cincin aromatik. Senyawa fenolik mudah ditemukan pada bagianbagian tanaman seperti batang, daun, bunga, dan buah (Vermeris dan Nicholson, 2006).

Antibakteri merupakan zat atau obat untuk membasmi jasad renik yang diperoleh dari sintesis atau yang berasal dari senyawa non organik. Bakteriostatik yaitu antimikroba yang hanya menghambat pertumbuhan mikroorganisme. Bakterisidal adalah antimikroba yang mampu membunuh mikroorganisme.

Penelitian sebelumnya dilakukan oleh Dzoyem et al. (2017) mengisolasi 4 jenis senyawa fenolik dari Entada abyssinica (Fabaceae) yang dapat bertindak sebagai antibakteri dan Khan et al. (2006) juga meneliti fraksi maniltoa schefferi memiliki aktivitas antibakteri yang baik. Maka peneliti tertarik untuk melakukan skrining dan menguji aktivitas antibakteri dari ekstrak daun tumbuhan saputangan.

\section{METODE}

\section{Bahan dan Peralatan}

Bahan: Ekstrak daun saputangan, metanol, DMSO, bakteri, $\mathrm{FeCl}_{3} 5 \%$ dan $\mathrm{CeSO}_{4} 1 \%$.

Peralatan: Maserator, Water Bath, Rotary Evaporator, Cawan Petri, Kertas Cakram dan Autoklaf.

\section{Preparasi Sampel}

Sampel adalah daun tumbuhan Saputangan (Maniltoa grandiflora (A.Gray) Scheff) yang diperoleh dari lingkungan Universitas Sumatera Utara. Determinasi tumbuhan dilakukan di Herbanium Medanense (MEDA) Departemen Biologi USU untuk memastikan jenis tanaman secara ilmiah. Daun segar tumbuhan Saputangan dikeringkan di udara terbuka dan dihaluskan, sehingga diperoleh serbuk halus sebanyak 2300 gram.

\section{Skrining Fitokimia}

Skrining fitokimia terhadap senyawa fenolik menggunakan pereaksi $\mathrm{FeCl}_{3} 5 \%$ terhadap ekstrak etil asetat dan metanol daun tumbuhan saputangan dan skrining terpenoida menggunakan pereaksi $\mathrm{CeSO}_{4} 1 \%$ dalam $\mathrm{H}_{2} \mathrm{SO}_{4} 10 \%$ terhadap ekstrak metanol daun tumbuhan saputangan.

\section{Maserasi Daun Saputangan}

Sampel diambil dari lingkungan sekitar Universitas Sumatera Utara. Sebanyak 2300 $\mathrm{g}$ daun tumbuhan saputangan yang sudah kering halus dimaserasi selama \pm 24 jam dengan pelarut metanol sebanyak 15 liter pada suhu kamar. Maserat disaring dan diperoleh ekstrak daun tumbuhan saputangan. Maserasi dilakukan kembali secara berulang-ulang menggunakan pelarut metanol sampai ekstrak metanol yang diperoleh memberikan hasil uji yang negatif pada pereaksi $\mathrm{FeCl}_{3} 5 \%$.

Ekstrak metanol yang diperoleh dipekatkan menggunakan rotary evaporator pada suhu $60^{\circ} \mathrm{C}$ dengan putaran $80 \mathrm{rpm}$ dan diuapkan hingga pelarut menguap sehingga diperoleh ekstrak padat yang kemudian dilarutkan dengan aquades sebanyak 1,5 liter kemudian diaduk hingga merata dan disaring sehingga diperoleh filtrat aquades yang selanjutnya akan dipartisi menggunakan etil asetat.

\section{Partisi Daun Saputangan}

Ekstraksi partisi daun tumbuhan saputangan dilakukan pada filtrat aquades di dalam corong pisah $500 \mathrm{ml}$ menggunakan pelarut etil asetat sehingga diperoleh lapisan bawah berupa aquades dan lapisan atas berupa etil asetat. Kemudian lapisan etil asetat diambil dan dilanjutkan partisi berulang terhadap filtrat aquades. Ekstrak etil asetat yang diperoleh kemudian dipekatkan menggunakan rotary evaporator pada suhu $60^{\circ} \mathrm{C}$ dengan putaran $40 \mathrm{rpm}$ dan diuapkan hingga pelarut menguap sehingga diperoleh ekstrak padat. 
Ekstrak padat bebas etil asetat dilarutkan dengan metanol, kemudian dimasukkan kedalam corong pisah dan dipartisi berulangulang dengan $\mathrm{n}$-heksana. Terbentuk dua lapisan yaitu lapisan bawah merupakan lapisan ekstrak metanol dan lapisan atas merupakan lapisan ekstrak n-heksana. Dilakukan partisi sebanyak 5 kali hingga lapisan n-heksana bening dan ekstrak metanol diuapkan hingga pelarut menguap sehingga diperoleh ekstrak padat bebas metanol yang memberikan hasil uji positif pada pereaksi untuk identifikasi senyawa fenolik.

\section{Antibakteri \\ Pembuatan Media}

Nutrient Agar: Sebanyak 28 gram nutrient agar, disuspensikan ke dalam aquades 1000 $\mathrm{ml}$, kemudian dipanaskan sampai larut sempurna. Media dimasukkan dalam labu dan disterilkan di dalam autoklaf pada suhu $121^{\circ} \mathrm{C}$ selama 15 menit.

Nutrient Broth: Sebanyak 13gram nutrient broth, disuspensikan kedalam $1000 \mathrm{ml}$ aquades, selanjutnya dipanaskan sampai larut secara sempurna. Dimasukkan media kedalam labu dan disterilkan di dalam autoklaf pada suhu $121^{\circ} \mathrm{C}$ selama 15 menit.

Media Miring: Dimasukkan sebanyak $3 \mathrm{ml}$ media nutrien agar steril kedalam tabung reaksi yang sudah disterilkan dan didiamkan pada temperatur kamar sampai membeku pada posisi miring membentuk sudut 30 $45^{\circ} \mathrm{C}$, selanjutnya disimpan kedalam lemari pendingin pada suhu $5^{\circ} \mathrm{C}$.

\section{Pembuatan Inokulum}

Koloni bakteri $S$. aureus diambil dari stok kultur menggunakan jarum ose yang sudah steril kemudian disuspensikan kedalam $10 \mathrm{ml}$ nutrient borth yang sudah steril kemudian diinkubasi pada suhu $35 \pm 2^{\circ} \mathrm{C}$ sampai didapatkan kekeruhan dengan transmitan 25\% menggunakan alat spektrofotometer UV panjang gelombang $580 \mathrm{~nm}$ (Irianto, 2006).
Dilakukan prosedur kerja yang sama untuk pembuatan inokulum pada bakteri E. coli.

\section{Pembuatan Stok Kultur Bakteri}

Dikembangbiakkan bakteri $S$. aureus dari strain utama yang diambil dengan menggunakan jarum ose yang telah steril kemudian diinokulasikan pada permukaan media nutrien agar miring selanjutnya diinkubasikan pada suhu $35 \pm 2^{\circ} \mathrm{C}$ selama 24 jam. Dilakukan prosedur kerja yang sama untuk pembuatan stok kultur pada bakteri $E$. coli.

\section{Pembuatan Larutan Senyawa Fenolik}

Konsentrasi ekstrak dibuat melalui larutan induk dengan konsentrasi $2 \mathrm{mg} / \mathrm{ml}$ dimana berat senyawa fenolik hasil isolasi daun saputangan digunakan sebanyak $2 \mathrm{mg}$ dan DMSO sebanyak $1 \mathrm{ml}$. Kemudian larutan induk diencerkan menjadi larutan dalam berbagai konsentrasi antara lain 1,$00 ; 0,5$ dan $0,25 \mathrm{mg} / \mathrm{ml}$.

\section{Pengujian Antibakteri}

Pengujian antibakteri dilakukan dengan metode difusi agar. Masing-masing dari inokulum bakteri diambil sebanyak $0,1 \mathrm{ml}$ dari bakteri $S$. aureus dan $E$. coli yang diusapkan dengan menggunakan cotton bud kedalam media nutrien agar. Dicelupkan kertas cakram ke dalam larutan senyawa fenolik (Pelarut DMSO) dengan variasi konsentrasi $(1,00 ; 0,50$ dan $0,25 \mathrm{mg} / \mathrm{ml})$, selanjutnya diletakkan di atas media yang telah diusapkan bakteri kemudian diinkubasi kedalam inkubator pada suhu $35 \pm 2{ }^{\circ} \mathrm{C}$ selama 18 - 24 jam, selanjutnya diukur diameter zona hambat menggunakan jangka sorong.

\section{HASIL DAN PEMBAHASAN Uji Skrining Fitokimia}

Skrining fitokimia fenolik terhadap ekstrak metanol sampel dan skrining flavonoida terhadap ekstrak etil asetat sampel diuji dengan penambahan $\mathrm{FeCl}_{3}$ 5\% memberikan 


\begin{tabular}{c|c|c}
\hline JURNAL PENELITIAN FARMASI HERBAL & VOL. 1 NO. 2 & $\begin{array}{c}\text { EDITION: NOVEMBER 2018 - } \\
\text { APRIL 2019 }\end{array}$ \\
\hline & http://ejournal.delihusada.ac.id/index.php/JPFH & \\
\cline { 2 - 3 } RECEIVED: 17 FEBRUARI 2019 & REVISED: 20 MARET 2019 & ACCEPTED: 25 APRIL 2019 \\
\hline
\end{tabular}

warna hitam menunjukkan bahwa ekstrak positif terhadap fenolik dan flavonoida.

Senyawa terpenoida dilakukan dengan meneteskan ekstrak metanol daun saputangan ke atas permukaan plat KLT kemudian disemprot dengan pereaksi $\mathrm{CeSO}_{4}$ $1 \%$ sehingga menghasilkan noda merah yang berarti mengandung senyawa terpenoida.

Tabel 1 Hasil uji skrining fitokimia ekstrak daun saputangan

\begin{tabular}{cccc}
\hline No & Golongan & Pereaksi & Hasil \\
\hline 1. & Fenolik & $\mathrm{FeCl}_{3} 5 \%$ & + \\
2. & Terpenoida & $\mathrm{CeSO}_{4} 1 \%$ & + \\
dalam $\mathrm{H}_{2} \mathrm{SO}_{4}$ & \\
3. & Saponin & Aquades & - \\
4. & Alkaloida & $\begin{array}{c}\text { Bouchardat } \\
\text { Meyer }\end{array}$ & - \\
& & Dragendorf & - \\
\hline
\end{tabular}

\section{Senyawa Fenolik}

Ekstrak padat hasil maserasi menggunakan metanol didapatkan sebesar 408,59 g. Kemudian dilanjutkan partisi menggunakan etil asetat sehingga didapatkan ekstrak padat menjadi $46,57 \mathrm{~g}$. Partisi terakhir dilakukan menggunakan n-heksana sehingga didapatakan ekstrak padat sebesar $36,96 \mathrm{~g}$ berupa senyawa fenolik.

\section{Antibakteri Senyawa Fenolik}

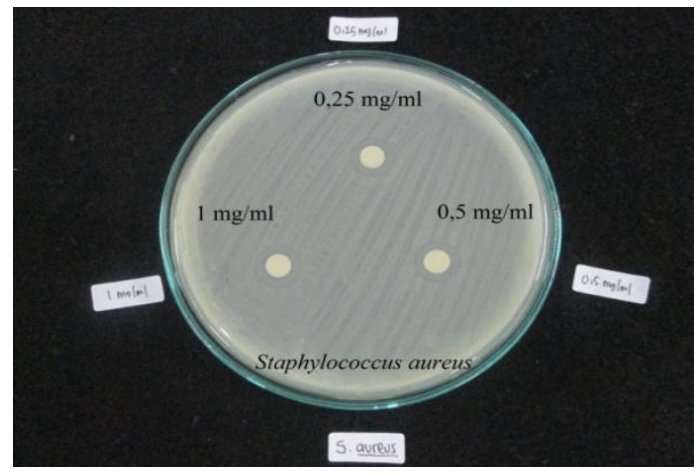

Gambar 2.a Diameter zona hambat senyawa fenolik terhadap S. aureus

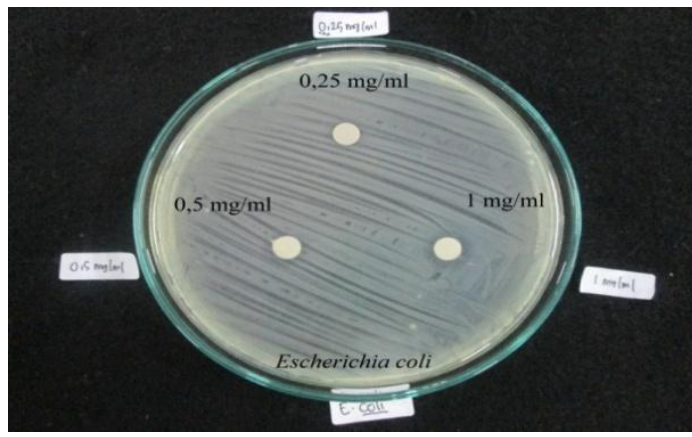

Gambar 2.b Diameter zona hambat senyawa fenolik terhadap E. Coli

Perhitungan zona hambat diukur pada seluruh diameter zona beningnya (beserta diameter kertas cakram). Dimana diameter kertas cakram yang digunakan berukuran 0,6 $\mathrm{cm}$ atau $6 \mathrm{~mm}$.

Tabel 2 Hasil pengukuran zona hambat aktivitas antibakteri

\begin{tabular}{cccc}
\hline \multirow{2}{*}{ No } & $\begin{array}{c}\text { Konsentrasi } \\
(\mathrm{mg} / \mathrm{ml})\end{array}$ & \multicolumn{2}{c}{ Diameter zona hambat } \\
\cline { 3 - 4 } & 0,25 & $7,3 \mathrm{~mm}$ & $8,1 \mathrm{~mm}$ \\
2 & 0,50 & $7,8 \mathrm{~mm}$ & $8,5 \mathrm{~mm}$ \\
3 & 1,00 & $8,5 \mathrm{~mm}$ & $9,7 \mathrm{~mm}$ \\
\hline
\end{tabular}

Maka dapat dinyatakan bahwa ekstrak DMSO senyawa fenolik dengan konsentrasi $(0,25$; 0,50 dan $1,00 \mathrm{mg} / \mathrm{ml}$ ) memiliki kekuatan antibakteri pada level medium yang mana zona hambat rata-rata pada bakteri $S$. aureus sebesar $7,87 \mathrm{~mm}$ dan zona hambat rata-rata pada bakteri $E$. coli sebesar 8,76 $\mathrm{mm}$.

Hal ini didukung oleh Davis dan Stout yang mengemukakan bahwa ketentuan kekuatan antibakteri adalah zona hambatan $20 \mathrm{~mm}$ atau lebih termasuk sangat kuat, zona hambatan 10-20 mm kategori kuat, zona hambatan 5-10 $\mathrm{mm}$ kategori medium dan zona hambatan $5 \mathrm{~mm}$ atau kurang termasuk kategori lemah (Mpila, 2009).

Perbedaan zona hambat dapat disebabkan oleh beberapa faktor antara lain besarnya inokulum, waktu inkubasi, konsentrasi ekstrak, dan daya antibakteri zat berkhasiat. Makin besar inokulum maka semakin kecil hambatnya sehingga semakin kecil zona 


\begin{tabular}{c|c|c}
\hline JURNAL PENELITIAN FARMASI HERBAL & VOL. 1 NO. 2 & $\begin{array}{c}\text { EDITION: NOVEMBER 2018 - } \\
\text { APRIL 2019 }\end{array}$ \\
\hline & http://ejournal.delihusada.ac.id/index.php/JPFH & \\
\cline { 2 - 2 } & REVISED: 20 MARET 2019 & ACCEPTED: 25 APRIL 2019 \\
\hline
\end{tabular}

yang terbentuk. Konsentrasi yang mempengaruhi kecepatan difusi zat berkhasiat. Semakin besar konsentrasi ekstrak semakin cepat difusi akibatnya semakin besar daya antibakteri dan makin luas diameter zona hambat yang terbentuk (jawetz, 2005).

\section{KESIMPULAN}

Ekstrak DMSO daun tumbuhan Saputangan mengandung senyawa fenolik yang memiliki zona hambat bakteri pada level medium dengan rata-rata zona hambat pada bakteri $S$. aureus sebesar $7,87 \mathrm{~mm}$ dan rata-rata zona hambat pada bakteri $E$. coli sebesar $8,76 \mathrm{~mm}$.

\section{DAFTAR PUSTAKA}

Dzoyem JP, Melong R, Tsamo AT, Tchinda AT, Kapche DG, Ngadjui BT, Mcgaw LC, Eloff JN, 2017. Cytotoxicity, Antimicrobial and Antioxidant Activity of Eight Compounds Isolated from Entada abyssinica (Fabaceae). Bio Med Central Research Notes, 10: 1-6.

Hidayati N, Mansur M, Juhaeti T, 2013. Variasi Serapan Karbondioksida $\left(\mathrm{CO}_{2}\right)$ Jenis-jenis Pohon di "Ecopark", Cibinong dan Kaitannya dengan Potensi Mitigasi Gas Rumah Kaca. Pusat Penelitian Biologi LIPI. Cibinong.

Irianto K, 2006. Mikrobiologi Menguak Dunia Mikroorganisme. Yrama Widya. Bandung.

Jawetz. EJ, Melnick L, Adelberg EA, 2005. Microbiologi Untuk Profesi Kesehatan. Terjemahan Huriati dan Hartanto. Penerbit Buku Kedokteran EGC. Jakarta.

Keller PA, Nugraha AS, 2011. Revealing Indigenous Indonesian Traditional Medicine: anti-infective agents. Natural Product Communications, 6 (12): 1953 - 1966.

Khan MR, Omoloso AD, Barewai Y, 2006. Antimicrobial Activity of the Maniltoa Schefferi Extracts. Fitoterapia, 77: 324326.
Mahidol C, Prawat H, Prachyawarakorn V, Ruchirawat S, 2002. Investigation of some Bioactive Thai Medicinal Plant. Phytochemistry, 1: 287-29.

Mpila DA, 2009. Uji Aktivitas Antibakteri Ekstrak Etanol Daun Mayana (Coleus atropurpureus (L) Benth) Terhadap Staphylococcus aureus, Escherichia coli dan Pseudomonas aeruginosa Secara In-Vitro. Manado: Fakultas Farmasi UNSRAT.

Solikin, 2009. Potensi jenis-jenis herba liar di Kebun Raya Purwodadi sebagai obat. Di dalam: Setiawan, Rahayu S, Rumhayati B, Alghofari AR, Naba A, Maryanto S, Widodo, (eds) Proceeding Basic Science National Seminar, Malang, February $21^{\text {st }}$ 2009, Malang: Brawijaya University. p VIII-47 -52

Vermerris W, Nicholson R, 2006. Phenolic Compound Biochemistry. Springer. The Netherla 